\title{
THE ROLE OF MULTINATIONAL OIL CORPORATIONS (MNOCS) IN NIGERIA: MORE EXPLOITATION EQUALS LESS DEVELOPMENT OF OIL-RICH NIGER DELTA REGION
}

\section{Oluwatoyin Oluwaremilekun Oluwaniyi ${ }^{1}$}

\section{Introduction}

The integration of world economies necessitated the establishment and spread of foreign direct investments (FDIs) globally owing to its potentiality as an important additional source of investment capital and managerial expertise. Due to the FDI potentials, developing countries have embraced Multinational Corporations (MNCs) as a source of economic progress, income growth, employment opportunities and poverty reduction, and the result so far, has been astounding. By 20I2, the value of FDI in developing economies, for the first time, surpassed that of developed economies with FDI flows to the Global South reaching over USD 700 billion (Anner and Hossain 20I4, 6). Findings garnered from the United Nations Conference on Trade and Development (UNCTAD I999) reveal that FDI continues to increase globally as multinationals operate in such economies. To further buttress this fact, in 2008, 82,000 MNCs controlled an estimated 8I0,000 foreign affiliates compared to 63,459 MNCs owning a total of 689,520 foreign affiliates in I998 (UNCTAD 2000; UNCTAD 2009). Interestingly, an estimated 425,000 of these affiliates are located in countries of the Global South, out of which, value added trade contributes at least $30 \%$ to Global South countries' GDP on average, as compared to I $8 \%$ in developed countries (UNCTAD 2013).

I Department of History and International Studies, Redeemer's University, Ede, Nigeria. E-mail: oluwaniyio@run.edu.ng 
Nigeria is not exempted from the integration of developing economies into the global capitalist system. The origin of Nigeria's integration can be traced to the influx of MNCs in the manufacturing and banking sectors during the colonial era. But by 1956, the discovery of crude oil in Oloibiri by Shell D'Archy, expanded the integration into the extractive sector and Multinational Oil Corporations (MNOCs) emerged as the main extractive bodies (Oluwaniyi 2010). From 1956, crude oil in the Niger Delta region has been central to Nigeria's political economy, accounting for over $90 \%$ of its foreign revenue, defining its place in 'international relations' (Raji; Yusuf and Samuel 2013, 24; Soremekun 20II, 99).

Though some scholars have associated multinational oil corporations with the development of host states, Niger Delta region continues to languish in deep poverty. The oil-rich communities fail to enjoy benefits commensurate to the profits gained by the levels of exploration of crude oil and exploitation in the region. This paradox further underlines the violent crisis perpetrated by frustrated youth in the region (Obi and Rustad 20II). Likewise, Angola, Equatorial Guinea, and Sudan are also among the top five sub-Saharan African oil exporters but, in terms of development, their performance have been dismal (UNCTAD 2007). The effects of MNOCs' presence have triggered debates on the extent to which they have contributed to the development or under-development in the region. It is against this background that it has become extremely pertinent to evaluate, in concrete terms, the effects of MNOCs' activities in the Niger Delta region. The objectives of this paper include, to analyse the extent to which multinational oil corporations have delivered on their larger expectations in the Niger Delta region, the role of the state in mediating or perpetuating crises between the MNOCs and the oil-rich communities, and impacts on relations in the region.

The study is an outcome of various field research studies across Delta, Bayelsa and River States, which were the most volatile areas in the Niger Delta, from 2004 till 2015. The studies employed both personal interviews and focus group discussions with affected locals, civil society groups and ex-militants. The communities include; Okerenkoko, which hosts ChevronTexaco and SPDC; and Kokodiagbene, which hosts SPDC. Both are Ijaw communities in Gbaramatu Kingdom, Delta State; Otuasega in Ogbia local government area of Bayelsa State hosts SPDC, Peremabiri hosts SPDC and AGIP pipelines), and Olugbobiri hosts SPDC and NAOC, They are in Southern Ijaw local government, Bayelsa State; Bukuma hosts SPDC, AGIP and Liquified Natural Gas (LNG) Company; Bakana. hosts Eroton Exploration and Production Limited (formerly hosted by SPDC) and Bille in Degema local government.; and Kegbare Dere in Gokana local government 
in Ogoniland, Rivers State, both have SPDC pipelines passed through their communities. The communities provide enough evidence to buttress the relationship between the MNOCs' activities and the underdevelopment of the oil-rich region.

Aside the introduction, section two focuses on a broad conceptual analysis of MNCs. Section three engages in the contextual analysis of MNOCs' operations in the Niger Delta while section four critically analyses the effects of MNOCs' operations in the region, citing primary data and the role of the State in consolidating and reinforcing the negative effects. Section five explores the current realities in the region in the aftermath of the amnesty programme. Section five is the conclusion.

\section{MNOCs in the Niger Delta Region}

The Niger Delta, which is the hub of oil and gas production, is one of the world's largest wetlands covering some $70,000 \mathrm{~km}^{2}$, formed by the accumulation of sedimentary deposits transported by the Niger and Benue Rivers (Azaiki 2007, I; World Bank Report I993, I). This does not infer that all oil producing states constitute the Niger Delta region (Ejovi et al 20I4, I42). In this context, the Niger Delta refers to areas identified with deltaic characteristics in the southern part of Nigeria, which include; Bayelsa, Rivers and Delta States and parts of Akwa Ibom, Cross River, Edo and Ondo States (Oluwaniyi 20I7).

The swampy terrain and fragile ecology, comprising extensive lowland tropical and fresh forests, aquatic ecosystem and biodiversity, basically form the region's pre-existing political economy and define the livelihoods of the local people as farmers, fishers, traders, food processors and local manufacturers of items linked to the principal subsistence economies (Amnesty International 20II). In fact, in pre-colonial and colonial eras, palm oil, a major agricultural produce in the region, served as a major source of export, foreign exchange, as well as, income for farmers ${ }^{2}$. But the emergence of crude oil and the dependence on MNOCs' extractive activities in the region have changed the economic base of the Nigerian state.

In I956, Shell D’ Archy (now SPDC) discovered crude oil in Oloibiri, now Bayelsa State, and by I958, it was available in commercial quantities through SPDC's distribution of its oil acreage to other oil multinationals,

2 Interview with Chief Mrs Josephine Ogoba, Warri Io August 2006; Mrs Victoria Abadi, the Kokodiagbene Women leader, 5 March 2009; and Chief Azulu in Olugbobiri, 7 March 20I3. 
including Mobil, Gulf (now Chevron), Agip, Safrap (now Elf), Texaco and others to mention but a few. Since the discovery of oil in commercial quantities, the region has proved to be the most prolific oil-producing area in Nigeria, containing seventy eight oil fields, including the largest, Forcados and Yorki (Ejovi et al 20I4). But it is imperative to note that the same swampy terrain that served as the livelihoods of the local people also attracted the extraction of crude oil in large quantities, thus distorting the organic agro-economy of the locals.

Obviously, the upswing in the production and revenues accruing from oil sale (especially from I97I rose from $\mathrm{N}_{4,733}$ million to 8880.8 million in I979) (Emenuga I993), led to the total neglect of non-oil sector of Nigeria's economy, and it culminated in the main strategic pivot around which Nigeria's developmental objectives were hinged.

Oil revenue rose to NI,4IO.7 million out of the total government revenue of N2.240.I million in I980, accounting for $53.8 \%$ of the total revenue accruing to the State (Amu I986). By I989, the share percentage of oil revenue (39,I30.50 million) on total revenue (47,798.30) was 8I.9\% (CBN I998). The figure for the period I990-I993 totalled \$199.3 billion. Nigeria earned so much from oil that a top government official was quoted as saying, 'money was not Nigeria's problem but how to spend it' (Owugah 2000, I05). Between I990 and I997, the value of oil export was above $95 \%$ of the total export. For instance, in I99I, the value of crude oil export was Niı6,856.5 million out of the total value of exports of NI2I,533.7 million representing $96.2 \%$, which increased to NI,065,501.60 billion out of the total export value of I,09I,I30.90 (CBN I998). By 3I December I995, the sale of crude oil and petroleum tax and royalties amounted to US\$7,898 billion (Anyanwu I997, 54). As at 2007, statistics showed that an estimated 23,I83.9 billion barrels of crude oil was produced in the Niger Delta and this amounts to a revenue of N29.8 trillion (Tell 2008). However, militancy affected oil revenues with the contribution of oil to total revenues, declining from 7I.7 percent to 69.2 per cent in 2012 (Bureau of Statistics 2013).

Owing primarily to oil revenues, the Nigerian economy was, in 2016 , rated in terms of GDP size as the largest in Africa, the $\sigma^{\text {th }}$ largest oil producer in Africa and ranked as the $12^{\text {th }}$ largest in the world (UNDP 20I6, 20). But ironically, while the federal government (in different regimes) embarked on structural infrastructural development, including elephant projects in non-oil areas, provided electricity to some countries in Africa and engaged in other humanitarian programmes in Africa and beyond, including peacekeeping; over $85 \%$ of the region's working population have no connection with the oil 
and gas industry and with low-wage/low productivity informal enterprises as its primary source of livelihood (UNDP 2006; Owugah 2000, I06). This represents a paradox of extreme wealth and extreme poverty and underdevelopment in Niger Delta region.

\section{Effects of Multinational Oil Companies' role in Nigeria's Niger Delta Region}

To say that the MNOCs' extraction of oil from the region's land has been a blessing, is to undermine the propensity of the development throes. As argued by residents,

oil is flowing in our backyards and communities, flowing day and night, and running into billions of dollars, and the real 'owners' have not gained anything: 3 there are no benefits as a result of oil exploration. No good schools... Everything is under-managed. Shell has over 30 wells and if AGIP comes around, we will have more than 50 wells, yet, there is no development. ${ }^{4}$

Thus, owing to the subjugation of the Niger Delta region to both MNOCs' onshore and offshore operations, the social relations of oil production has penetrated the social structure of the local communities and defined their space, largely as the excluded, the alienated, and the exploited" in the larger Nigerian society (Ibaba 2005, I3-I4).

Environmental degradation, through oil spillages and gas flares, forms the crux of MNCs definition of the space of alienation and exploitation perpetrated by the MNCs. Between I976 and I996, an estimated 2,369,47I barrels of crude oil was spilled, either while prospecting for oil and gas or due to leaking pipes, out of which, I,820,4II were not recovered and were therefore, absorbed by the soil (Okaba 2005). By 20II, it was observed that a total of 2.4 million barrels had been leaked into the delta (Ekubo and Abowei 20II). In most Ogoniland communities, especially K-Dere and Bille, their drinking water is totally contaminated with high levels of hydrocarbons, thus jeopardising their health. ${ }^{5}$ In the absence of alternative sources, inhabitants

3 Interview with Apaingolo Ebipatei, at Obubra Amnesty camp, August 9, $201 \mathrm{I}$

4 Interview with Toby, the Youth Vice President in Peremabiri, 5 March 2013

5 During my visit to those two places, I saw farmlands that had been polluted by oil. 
fetch dark, oily river water to cook and drink. ${ }^{6}$ Humanitarian assistance has been mostly externally motivated or driven by philanthropists in form of provision of boreholes in order to save communities from potential or immediate health crises. ${ }^{7}$ In other cases, self-help in terms of collective or community effort has helped to provide underground water. But, most times, owing to lack of funds, such projects are totally abandoned over reaching crude oil, leaving the inhabitants without other options but to rely on the river as the major source of survival. ${ }^{8}$ In other communities, burying of the dead in the backyards of home, which is a cultural belief system that serves as strong iconic image of people, counters modern digging of boreholes. ${ }^{9} \mathrm{As}$ at the time of study in Peremabiri, underground water was available only in the Guest House and ex-warlord Ogunboss' residence. ${ }^{\text {IO }}$

The United Nations Environmental Programme (UNEP) (20II) affirms that due to the drifts of the Niger Delta's creeks and rivers, which flow into the Atlantic Ocean, oil spillage in one community may spill over into other communities. In areas where the effects of such spills were not obvious, they were 'severely contaminated' underground, thus, threatening human security in the region. In fact, 'the river meant for fishing has been neutralised by excess crude oil. '्I In Ogoniland, Rivers State and Otuasega, Bayelsa State, oil spills on farmlands stunted the growth of some farm produce, affected the existence of some species of cocoyam and plantain, and the prices of available farm products in the market. ${ }^{12}$ It also affected some fauna products. In recent times, aqua products are usually very small and even contaminated. ${ }^{13}$ Most times, women sell contaminated sea foods

6 Research studies in K-Dere, Ogoniland; Otuasega, Peremabiri and Olugbobiri in Bayelsa State; and Kokodiagbene in Delta State at various periods confirmed this disaster.

7 Interview with Joshua Inifa in Bukuma on II February 20I3, revealed that a National Youth Service Corp (NYSC) female member donated a completed borehole to the Bukuma community in 2012 .

8 Interviews with residents in K-Dere, Bille, Olugbobiri, and Bakana.

9 Interviews with different categories of people in Peremabiri, including chiefs Karibo (Snr) and Kologbo, youth vice president, Tobi; and CDC Secretary, Siri, in March 2013. Interview with Jams Ugbokiri, Uju CDC Chairman Similar culture exists in Okrika.

Io I stayed at the Guest House with my research assistant and I observed that villagers entered the guest house to fetch water from the underground source.

II Chief General Okei (the spokesperson for the $3^{\text {rd }}$ Phase ex-agitators) in a focus group discussion with General Parker, General Godbless Ozoto and General Andrew on 5 December 2012

I2 Author was taken to the spill sites.

I3 Interviews with market women in Delta and Rivers States in 2006 and 2013 respectively 
for profits, leaving the buyers to high risk health issues. ${ }^{\mathrm{I4}}$ Sometimes, due to the thickness of the oil spills, fishing nets are damaged. But unfortunately, oil companies in those communities fail to provide new nets, pay compensation for damaged nets or find alternatives to traditional fishing mechanism, and whenever payment is made, it is always a far cry from what has been damaged. ${ }^{15}$ The result is economic hardship for hundreds of families who depend on fishing and farming to survive, thus posing a huge threat to human security. ${ }^{16}$ In fact, it would take SPDC, 30 years and a cost of \$Ib to clean up the spills in Ogoniland (Obi 20I2). Prior to the exploration of crude oil in commercial quantities, women could till the land for several years but currently, the MNOCs activities have totally hindered such opportunities.

In a bid to evade compensation for damaged flora and fauna, MNOCs make claims that most spills were caused by sabotage, and in accordance with the Nigerian law, compensation is lost in such cases. The conclusion that sabotage has occurred is largely left for MNOCs to determine, increasing the chances of injustice towards victims. ${ }^{17}$

To worsen the repressive conditions of locals, gas is flared non-stop, without due consideration to their health, economic survival and environment generally. In fact, getting close to the gas flare zone could be likened to roasting meat or fish at a high temperature level. ${ }^{18}$ Though, Nigeria has moved from the second highest gas flaring state (with $80 \%$ gas burned off) to the seventh with Russia, Iraq, Iran, United States, Venezuela, and Algeria topping the list, the gas flaring percentage is still high at I0\% (Okafor 20I7; Igwe 2009, 6-9). Meanwhile, the penalty against flaring, which is Nio per I, O०० scf of associated gas flared seems extremely low to compensate for the losses of lives and property, having been eroded in value over time, and is not acting as intended, as a disincentive (Asu 20I7). In this regard, the low penalty granted by the state for the systematic toxification of the region provides a much cheaper option, as well as, increases the arrogance and lackadaisical attitude of

I4 Interview with Mr. Jonjon, the Ijaw Youth Council leader at the IYC office, Yenagoa on 4 April 2005.

I5 FGDs with chiefs in Peremabiri in March 20I3. They complained bitterly about the loss of their fishing nets to a huge oil spill in the environment and how SPDC refused to compensate them. Women leader in Bakana also complained bitterly about the loss of fishing nets and even boats to oil pollution

I6 Interviews with women at home and market areas at Warri, and Yenagoa

I7 Interview with NGOs such as ANPEX and Living Earth Nigeria Foundation in Rivers State, August 20II as well as NDDC representative at the NDDC Office, Yenagoa, Rivers State in December 20I2.

I8 Author's encounter during visit to the gas flaring areas at Otuasega, in 2005 and Olugbobiri, Southern Ijaw, Bayelsa State in 2013. 
the oil companies. Meanwhile, such reckless attitudes do not exist in western countries' corporations where same oil corporations operate. ${ }^{19}$ To Ejovi et al (20I4), the interest of the oil multinationals is squarely profit maximization, and as a result, they disregard existing global environmental regulations and laws by capitalizing on the weak cum ineffective State enforcement and implementation of the laws. The health impacts of oil spills and gas flares are unquantifiable. While oil spills culminate in painful body outgrowth and child deformities, gas flares results into serious respiratory health problems. ${ }^{20}$

The effects of these devastating incidences by the oil industry is such that people no longer engage in productive farming, fishing, and hunting as they could have. In the words of Owugah (2000, I09), 'the confidence and security which the people had in the capacity of their natural environment and in their own capacity to harness the resources of their environment, to sustain their psycho-social needs, have been greatly eroded by the devastating effects of the activities of the oil companies on their environment and their means of livelihood.' The living conditions of locals do not reflect the presence of such rich MNOCs in the affected areas (UNDP 20I6, 20). For instance, it is important to note that the SPDC began operations in Kegbare Dere (or K-Dere) in I958 and it has 57 oil wells out of the 96 oil wellheads in Ogoniland, yet the living conditions are utterly dismal and pitiable. ${ }^{2 \mathrm{I}}$ Despite the number of oil companies operating in Peremabiri and Bakana, both communities remain totally underdeveloped. Most of their youths are either unemployed $^{22}$ or employed at the lowest rungs of the employment ladder, usually on contract basis. ${ }^{23}$ Based on MNOCs' request, youth and sometimes, CDC leaders recruit specific number of community youth to cut grasses, repair pipes and cast band walls in order to contain the level of gas flares. ${ }^{24}$ Sometimes, SPDC give out Sit-at-Home allowances to youth in aggressive or potentially aggressive communities to act as a gauge to alleviate their destructive capacity on oil pipes. ${ }^{25}$

I9 Nigeria lost 2I7 bn to gas flaring in 2016-NNPC 24 See Punch February 2017.

20 My research assistant's son in Olugboiri had a large growth in right eye.

2I Research studies conducted in K-Dere, an Ogoni community in 2005 and 20II; and for Peremabiri and Bakana in 2013.

22 Focus Group Discussion with Generals Okei, Andrew, Parker and Godbless Ozonto in Yenagoa, I5 December 2012; Interview with the Bakana Community Development Association (BCDA) Financial Secretary, Apostle Abioton Allison in Bakana, I4 February 2013.

23 Interview with Chief Kosini and FGDs with youth members in Olugbobiri on 7 March 20I3 24 Interview with Toby revealed that he selected 30 youth in Peremabiri, as requested by SPDC, to help cast band walls.

25 In Otuasega, the Youth leader Christian Igbedon revealed that two youth each were paid N30,000 for three months and afterwards, rotated among the youth population successively. 
Nevertheless, MNOCs have, in some way, contributed to development in the region. Right from the I990s, they have implemented many CSR policies, particularly focusing on 'development' projects in the region such as townhalls, market stalls, cottage clinics, schools, electricity (through the purchase and installation of generators), and jetties. ${ }^{26}$ Some of the projects were executed through the Grand Memorandum of Understanding (GMOU) signed between oil companies and groups of communities, known as clusters. Most times, the clusters do not work since decisions about the kinds of projects to be implemented, the cost and fund sharing vary for each community. The variations usually breed conflicts among such communities. For Joshua,

everything is based on cluster and Bukuma community is not ready to be in any cluster since the resource we have is more than that of other communities, for us to share the proceeds equally...Cluster sharing brought total breakdown of law and order between Bukuma and Tombia. The money shared cannot do anything tangible for us. But if the money goes directly to the community which needs it, they can implement their projects very well.

Moreover, majority of the social facilities provided in the oil-rich communities are extremely inadequate in terms of quantity and quality to cater for the needs of locals. ${ }^{27}$ Due to lack of MNOCs' proper monitoring or maintenance of these facilities, they wear out easily without any form of replacement, ${ }^{28}$ leaving communities vulnerable, and also give their youths, the opportunity to siphon or cart away such facilities for their personal gains. ${ }^{29}$ While cottage clinics in some communities lack personnel, including doctors, ${ }^{30}$ other oil-rich areas do not even have clinics. ${ }^{3 \mathrm{I}}$ In the latter case, sick people have had to move to other nearby or mostly, far distant communities where such services exist with bicycle, motorcycle or boat utilised as means of transportation..$^{22}$ Similarly, education in such communities is stagnant and

26 Interviews in different communities.

27 Interviews with youth groups, women groups, chiefs, ex-militants and residents in the cases over the years.

28 Observations during research visits in 20I3. Throughout my one-week stay in Peremabiri, there was no electricity in the whole Peremabiri, except for a few households that could afford the 'I better pass my neighbour' (small generators) model.

29 Interview with a Niger Delta oil-rich community resident at Ede, Io October 2017.

30 Close discussion with a mother whose son had eye tumour revealed that the clinic there could not help and she had to take her son to the General Hospital at Yenagoa, from where they were referred to Teaching Hospital in Port Harcourt, Rivers State.

3I Interview with Alaso Jonah, a farmer in Bukuma on I2 February 20 I3.

32 Observations in Bukuma and Bakana. 
it lacks the full participation of MNOCs and the State, hence, most of the structures have become dilapidated and their teachers are left discouraged. ${ }^{33}$ All these problems have turned the region into 'a locale with social level of dispossession.' In defence of their exploitative activities, SPDC argues "we do not hold the solution to community demands for more amenities, development, more employment and more control over oil revenues. That is primarily a government responsibility" (Boele et al 2007, 76). Kidnapping for ransom, killing and hostage-taking created chaotic situations and scared most oil companies such as; SPDC, Chevron, and Mobil to mention but a few while their subsidiaries such as; Wilbros, an American oil service company and Indorama, operators of the Eleme Petrochemical Company Limited, also shut down or shifted base to Lagos and Abuja owing to incessant kidnapping of its workers. The insensitivity and insincerity of the MNOCs to the crises deliberately caused by their operations raises questions about the effectiveness of the terms of agreements signed between MNOCs and the Nigerian state on one hand and of how reliable the state is in dispensing justice against erring oil companies on the other.

\section{Beneficiaries and losers in MNOCs' extractive operations}

Within this context of global oil capitalism, some groups have emerged as beneficiaries while others, as losers. Undoubtedly, the first set of beneficiaries remains the MNOCs whose major, if not, only interest is the maximisation of profit and accumulation of capital. From I958 to 2012, SPDC's revenue yielded about \$30 billion in oil revenues, subordinating the lives and livelihoods of the locals through frequent oil spills, blow outs, seismic blasts, gas flaring, discharge of effluents directly into their water bodies. The State assists MNOCs' profit making through reduction in taxes paid to the state; tax evasion; decrees such as the Anti-Sabotage Decree of I975, which imposed death penalty or imprisonment of not more than 2I years for activities that obstruct the production and distribution of crude oil, and the Land Use Act of I978, which vested the ownership of all land and resources on and inside in the State; and militarisation of the oil blocs and companies. The impunity of MNOCs has deepened crises in the region (Ukeje 2005, 328).

Since the global interests of uninterrupted oil production coincides with the interests of the state and its dominant social forces that depend on oil revenues, the State has emerged as the second category of beneficiaries in the

33 In Olugbobiri, Peremabiri, and Bukuma, their schools were in total disarray and needed urgent renovation. 
oil political economy. The host state in the global south is depicted as a captured state in a triple alliance, compelled to advance and protect the interests of international capital, including oil investments in petro-accumulation (Omeje $2005,32 \mathrm{I})$. Within this network of advancing the interests of international capital, state bureaucrats and managers are able to accommodate and satisfy their own interests via the reaping of natural resource rents and expansion of the frontiers of corrupt enrichment and misappropriation of public resources. In this context, since the state is dependent on rents from oil sales, it largely sacrifices the well-being of the populace in policy making and governance in preference to the interests of international capital while maintaining an unholy alliance with the MNOCs, and with the paraphernalia of force, subjugate oil-rich communities. Closely in the third category and depending on the stratification of the Niger Delta communities are the chiefs and elders on one hand, and the youths on the other.

From the above, there is no gainsaying that the losers and victims of the oil-politicking are the poor and voiceless oil-rich rural dwellers, especially, women, and their victimisation could be measured in two ways. Firstly, it is interesting to note that women experience degradation, despoliation, vulnerabilities and marginalisation in more terrifying ways than men. Generally, women in the rural areas engage in precarious livelihoods in a bid to eradicate poverty and hunger. Likewise, in the Niger Delta region, women there are mostly fishers, farmers and traders, and the proceeds from their sales of such products are fully devoted to their households. Therefore, any distortion in form of pollution on land and rivers, including spills and flares, would affect women more and such scenario would worsen their vulnerability. Unfortunately, their central role in food security is largely ignored by the extractive industry. Secondly, in spite of their roles and vulnerabilities, they are also maligned in the policy making that largely affect them. Patriarchy gains preference in a male-dominated society like the Niger Delta, and so, issues that affect women and children are determined by the male folk. Evidences have revealed that women lack the agency to question the oil capital and their men. ${ }^{34}$

\section{Dealing with the losses: locals resistance vs MNOCs' reaction}

As losers in the politics of oil, the poor seek alternatives to their survival. For girls and women, navigation into prostitution is the most

34 Interview with Grace, a woman in Olugbobiri, II March 2013. 
profitable (Oluwaniyi 20I0). Some girls forcibly rely on relatively rich men, mostly in the oil and gas sector, 'as camp followers' by ensnaring them with pregnancies, which most times, are rejected by their 'supposed owners' thus, worsening poverty conditions. ${ }^{35}$ For men, their alternative survival strategy ranges from banditry, stealing, oil bunkering to sea piracy. The consciousness of exploitation, marginalization and disempowerment makes the region, a site of deep-rooted frustration and conflict.

With the failure of the rentier state to mediate between the MNOCs and locals in the region, grievances aggravated from non-violent actions overtime to actual violence overtime. Violent resistance became the last alternative available, and usually in response to the violence of the state, which it is believed could intimidate the aggrieved into silence by using repressive forces. (Owugah 2000, II4). Non-violent actions include; taking legal actions against the oil companies for adequate compensation over damages to their land and waters, and the formation of ethnic or community-based groups varying from one community to another but with the same goal(s). For the ethnic groupings, MOSOP was the first ethnic-based organisation (Movement for the Survival of the Ogoni People), established to contest antidevelopment in the region, followed by others such as the Ijaw Youth Council (IYC), which organised rallies and cultural processions; Isoko National Youth Movement (INYM); and Egi Youth Federation (EYF) among others, Ethnic national groups such as Elimotu Movement, Ijaw National Congress (INC) and Egbema National Congress were also involved. Women were very active in those groups. They helped to mobilise fellow women during protests. However, the female intellectuals were more daring, bold and confrontational during the oil struggle. ${ }^{36}$

There were pan-ethnic civil groups such as; the Chicoco Movement (CM) and the Niger Delta Women for Justice (NDWJ). These groups cut across ethnic boundaries and were very active in the region's struggle. Lastly, the emergence of non-governmental environmental organizations drew the attention of the public to life-threatening ecological problems and engendered livelihood of the locals, which intensified their social mobilization to demand for grassroots empowerment. Those groups were the Niger Delta-Human and Environmental Rights Action (ND-HERO) and the Environmental Rights Action (ERA). Some members of these groups also belonged to the ethnic and pan ethnic-based bodies. They also constituted the intellectual and scientific

35 Interview with Chief Azulu on 7 March 2013 and Otuasega CDC Public Relations, Nelson Adams in Otuasega, 5 April 2005.

36 Interview with the IYC Secretary in Yenagoa, Bayelsa State, 7 February 2014. 
wings of the mass-based militant Ijaw Youth Council (IYC) (Ukeje 2002, 30). Of these groups, the youth groups were the most vociferous, active and violent in their activities and methods.

From the mid-I990s to mid-200os, the struggle took a violent but, non-military dimension. Such violence implied the vandalisation of MNOCs properties, seizure of its boats and blockage of oil flow stations among other activities. Corroborating this fact, an interviewed ex-militant at the Obubra camp argued that, 'I am from Egwema community. If you get to my community, there is no light, no water but we are the ones promoting Nigeria because of oil, compared to other regions. It is due to this marginalisation that we decided to engage in violent struggles against the SPDC and Federal government.' 37 Since the SPDC operates most of the on-shore fields, which are easily accessible, it was the most affected in the violent struggles. Of the 631,000 bpd that Nigeria lost in 2007, SPDC alone accounted for 455, 000bpd, Agip, 75,000 and others I2I,000 (Agbo 2008, 25). Despite the losses, SPDC paid some compensation to quell the violent protests but they were given to the 'wrong hands', thus further turning it to a full-fledged militancy from the mid-2000s..$^{8}$ The protests in the region explain the rising demands of the deprived/marginalised social groups in view of actual longings for justice and equity. In retaliation, the comprador Nigerian State destroyed its own masses, including the elderly, women and children, through the use of the armed forces, Mobile Police (MOPOL) and international military support in furtherance of the MNOCs' agenda, particularly, SPDC's predatory interests (Asuni 2009). 39

The current post-amnesty programme by the Federal government - which emphasises disarmament, demobilisation and reintegration (DDR) of ex-militants - is expected to facilitate economic reconciliation and development of the region. Although, much has changed with the role of multinationals in the post-amnesty era through the signing of the GMOU with some clusters in the oil-rich areas to enhance participatory governance in the social development of their communities, the fact remains that the State has failed to positively re-engineer or transform the region's environment. Five years after DDR, the issues that led to militancy still remain, explorative activities still remain uninterrupted and oil-rich communities are still wantonly degraded; divide and rule is still utilised to the chagrin of rural stakeholders; inclusive governance as well as institutionalised representation of communities in decisions is still

37 Interview with Nicholas Asieman at the Obubra Amnesty Camp, 5 August 20 II.

38 Interview with Inifa Joshua.

39 Interview with Monday Sample in Yenagoa, April 2013. 
very much absent within the GMOU structure and general development of the region, and MNOCs, particularly SPDC are still recalcitrant about cleaning oil spills, and compensating affected farmers and fishers. Moreover, MNOCs' contributions to the success of the post-amnesty programme process have been very meagre. For instance, while the federal government focuses on full empowerment through education and vocations for ex-militants to the tertiary levels, MNOCs limit their empowerment programmes to vocations that do not exceed six months. Moreover, out of the 30,000 ex-militants, they selected 3,000 ex-militants only, leaving the bulk of the responsibilities to the federal government. This shows the centrality of the MNOCs' interests as well as its insincerity to develop the region. ${ }^{4 \circ}$ Comparing the development between the region and the countries where they were trained, some ex-militants perceived those countries as 'light' and theirs as 'darkness.' ${ }^{41}$ Realistically, it shows that their communities lack every form of development in relation to the infrastructural development of the countries' communities where they had stayed. Lastly, there has been continuous concentration of wealth and power in a few hands, and corruption and increasing inequalities are perpetrated by the MNOCs in collaboration with the Nigerian State.

As a result of these post-amnesty challenges, new threats have resuscitated in the region, ranging from protests, kidnapping, hostagetaking, gun-running and threats to return to the creeks (Oluwaniyi 20I7, 35). Rather than being governed in more participatory, equitable and sustainable development of host communities, the extractive nature of the MNOCs has resulted in global dynamics of dispossession of land and resources whilst creating new forms of dependency and domination in resource-rich countries in Asia, Latin America and Africa generally. Such unbridled accumulation is accompanied by an explosion of socio-environmental conflicts, prosecuted by victims in those societies. The crises portend dangers for countries' growth and development, and from the case of the Niger Delta region, violent conflict and destabilisation of the meagre development process, revive and complicate old conflicts about identity, citizenship, leadership and governance (Omeje $2008 \mathrm{~b}, 8)$. More disheartening is the fact that their presence has limited the possibilities for the predatory Nigerian state to diversify its economy that would create the environment for sustainable economic growth and development, and poverty reduction of the rural poor.

40 Interview with Professor Ibaba, Niger Delta University, Wilberforce, Bayelsa State on I3 December 20I2.

4I Interviews with ex-militants who had travelled to South Africa, Malaysia and Ghana, and had returned to their communities in Bayelsa and Rivers States. 


\section{Conclusion}

From the foregoing, it is apparent that the MNCs promote underdevelopment of host states, especially, in developing countries. Their ambition to achieve global capitalism has produced unequal development between the developed countries and the developing ones, immiserating the latter further into poverty rather than development. Their operations in Nigeria's Niger Delta region clearly accentuate this perception. Some of the challenges of development faced by the region include; environmental degradation in the form of oil pollution and gas flares, poverty, inadequate diffusion of appropriate technologies, institutional weakness, disruptive economic forces, policy distortions and inequity, inadequate education, lack of appropriate methods for resource valuation and promotion of conflict, militancy and proliferation of arms.

However, the significance of MNOCs cannot be overemphasized in this current global age due to Nigeria's low technological capacity and funding capability. Thus, in order to maximise benefits over its resources, the Nigerian state will need to anchor on the strengths of the MNCs (UNCTAD 2007,82 ). But how can Nigerian state maximise its benefits and minimise its cost on oil-rich areas in particular?

The State should leverage on its power as the resource-state to determine the kinds of foreign investments that will benefit its inhabitants, who should invest, and the conditions guiding the investments must be strictly adhered to. This is to ensure that the State is not subjected to any foreign economic domination and will further sustain the government's direct positive intervention and transparency. Strict laws followed by appropriate sanctions that must guide oil companies' investments, safeguard the rights of communities and avoid growing tensions between communities and investors must be put in place. These include; corporate environmental policy such as total banning of gas flares, non-imposition of infrastructural facilities on communities, and training and retraining of local staff, green environment and clearing of oil spills, adequate compensation for destroyed lands as well as sustainable management of the environment. In the same vein, the process of money sharing in the region, which has resulted into unending conflict, should be eliminated. Rather, the funds should be diverted into the industrialisation of the region's economies in order to generate employment opportunities to the teeming unemployed youth there. ${ }^{4^{2}}$ The civil society

42 Between I999 and 2000, I2I persons died in Peremabiri as a result of 'money sharing' conflict. 
should be encouraged to take a major role, defending the rights of the oil-rich, but underdeveloped communities with a focus on the collective and security needs of the locals in the Niger Delta region.

\section{REFERENCES}

Ahiakpor, James C. W. 20I6. "Multinational Corporations in the Third World: Predators or Allies in Economic Development?" Religion and Liberty, 2(6), July

Agbo, A. 2008. "Hostage Economy: Oil Firms Flee Niger Delta”, TELL, 23, June 9, 2008

Ake, C. I98I. A Political Economy of Africa. London: Longman

Akinlo, A. E. 2004. "Foreign Direct Investment in Nigeria: An Empirical Investigation”, Journal of Policy Modelling, 26: 627-39

Anner and Hossain, 20I4. "Multinational Corporations and Economic Inequality in the Global South: Causes, Consequences and Countermeasures" Paper Prepared for the $9^{\text {th }}$ Global Labour University Conference, "Inequality within and Among Nations: Causes, Effects and Responses", Berlin, I5-I7 May 20I4

Anyanwu, J. C., Oyefusi, S. A. , Oaikhenan, H, Dimowo, F.A. I997. Structure of the Nigerian Economy (1960-1997). Onitsha: Joeanne Educational Publishers

Aremu. 2005. Attracting and Negotiating Foreign Direct Investment with Trans-National Corporations (TNCs) in Nigeria. Lagos: Market Link Communications

Asu, F. 20I7, "Nigeria Lost N2I7bn to Gas Flaring in 2016", The Punch, February 23

Asuni, J. B. 2009, Blood Oil in the Niger Delta. USIP Special Report. Washington: United States Institute of Peace

Baran, P. I973. The Political Economy of Growth with an Introduction by R. B. Sutcliffe. Harmondsworth: Penguin Books

Boele, R., Fabig, H., Wheeler, D. 200I. "The Story of Shell, Nigeria and the Ogoni People - Environment, Economy, Relationships: Conflict and Prospects for Resolution." Sustainable Development. 9:74-86.

CBN. I998. CBN Statistical Bulletin. Abuja: CBN 
Ejovi, A. Ebie, S. and Akpokighe, O. 20I4. "Globalization and Environmental Degradation of the Niger Delta Region of Nigeria," Research on Humanities and Social Sciences 4 (13): I42-I52

Ekubo and Abowei. 20II. "Aspects of Aquatic Pollution in Nigeria" Research Journal of Environmental and Earth Sciences, 3 (6): 673-693

Eze, W. 20I3. "Oil Exploration and Corporate Social Responsibility- A Case of SPDC Global Memorandum of Understanding (GMoU)" Global Journal of Human Social Science, Sociology and Culture, I3 (2): I5-2I

Facing Finance. 2004. "Royal Dutch Shell in Nigeria". http://www.facing-finance.org/en/database/cases/royal-dutch-shell-in-nigeria/

Frynas, J. 2005. "The False Development Promise of Corporate Social Responsibility: Evidence from Multinational Oil Companies." International Affairs 8I(3):58I-598.

Frynas, J. 2000. Oil in Nigeria: Conflict and Litigation Between Oil Companies and Village Communities. Hamburg: LIT VERLAG

Gahel, M. and Bruner, H. 2003. Global Inc. New York: New Press

Ghani, F. 20I5. "Economic Role of MNCs in Developing Countries: A Case Study of Pakistan", Journal of Political Science XXXIII, 70

Halperin, S. I997. "In the Mirror of the Third World: Capitalist Development in Modern Europe. Ithaca, NY: Cornell University Press

Ibaba, S. I. 2005. Understanding the Niger Delta Crisis. Port Harcourt: Amethyst and Colleagues

Ikelegbe, A. 2004, "Crisis of Resistance: Youth Militias, Crime and Violence in the Niger Delta Region of Nigeria" African Studies Centre Seminar, Leiden, the Netherlands on $5^{\text {th }}$ August.

Karl, T. L. I997. The Paradox of Plenty: Oil Boom and Petro-States. Berkeley: University of California Press

Marchant, M. 20I4. CSR and Oil in the Niger Delta: Solution or Part of the Problem? http://www.unrisd.org/ystp-marchant

Nwankwo, A. 20II. "After Oil, what Next?" Journal of Africa in a New World Order 3 (2) 20-30

NNPC. 20I7. "Joint Venture Operations", http://nnpcgroup.com/NNPCBusiness/UpstreamVentures.asp

Obi, C. 20I2. "Africa's International Relations Beyond the State: Insights from the Niger Delta" Tim Murithi (ed), Handbook of Africa's International Relations. London: Routledge 
Obi, C. and Rustad, S. 20II. "Introduction: Petro-Violence in the Niger Delta-the Complex Politics of an Insurgency", C. Obi. and S. Rustad (eds), Oil and Insurgency in the Niger Delta London: Zed Books, I-27

Obi, C. 2004. "Globalization in Nigeria's Oil Industry: Implications for Local Politics" A. Agbaje et al (eds), Nigeria's Struggle for Democracy and Good Governance, A Feetschrift for Oyeleye Oyediran. Ibadan: University Press

Okaba, B. O. 2005. Petroleum Industry and the Paradox of Rural Poverty in the Niger Delta, Benin City: Ethiope Publishing

Okafor, C. 20I7. "NNPC: Nigeria Drops to Seventh Highest Gas Flaring Country,. https://www.thisdaylive.com/index.php/2017/04/03/nnpc-nigeria-drops-to-seventh-highest-gas-flaring-country/

Oluwaniyi, O. O. 20I7. "The Challenges of Reintegration in Post-Conflict Peacebuilding: The Case of Nigeria's Niger Delta Region.” African Peacebuilding Network (APN) Working Paper (to be published) . 20I4. Post-Amnesty Reintegration and Peacebuilding Challenges in Nigeria's Niger Delta Region: The Way Forward" in Kujenga Amani, April 7

. 20IIa. Women's Protests in the Niger Delta", C. Obi. and S. Rustad,(eds), Oil and Insurgency in the Niger Delta London: Zed Books, I50-166

. 20IIb. "Post-Amnesty Programme in the Niger Delta: Challenges and Prospects" Conflict Trends, Issue 4.

. 20I0. "Oil and Youth Militancy in Nigeria's Niger Delta Region", Journal of Asian and African Studies 20 (IO), I-I7

Omeje, K. 2008b. "Extractive Economies and Conflicts in the Global South: Re-engaging Rentier Theory and Politics" Kenneth Omeje (ed), Extractive Economies and Conflicts in the Global South: Multi-Regional Perspectives on Rentier Politics. Aldershot: Ashgate.

. 2006. High Stakes and Stakeholders: Oil Conflict and Security in Nigeria. Aldershot: Ashgate.

. 2005. "Oil Conflict in Nigeria: Contending Issues and Perspectives of the Local Niger Delta People" New Political Economy io (3), 32I334

Owugah, L. 2000. Political Economy of Resistance in the Niger Delta Benin City: ERA/ Friends of the Earth. 
Rawlings, S. 2007. The Multinational Companies: Instrument for World Growth" Journal of Commerce 5 (2), 25-33

Ruccio, D F. 20I2. Development and Globalisation: A Marxian Analysis. London: Routledge

Soremekun, K. 20II. "Nigeria's Oil Diplomacy and the Management of the Niger Delta Crisis" C. Obi. and S. Rustad,(eds), Oil and Insurgency in the Niger Delta London: Zed Books, 99-II4

te Velde, D. 200I. Policies Towards FDI in Developing Countries: Emerging Best Practices And Outstanding Issues. London: Overseas Development Institute. March

Todaro, M. P. and Smith, S. C. 2003. Economic Development. Bloomberg: Pearson Education Limited

Todaro, M. P. I98I. Economic Development in the Third World $2^{\text {nd }}$ ed. London Ukeje, C. 2002. "Oil Communities and Political Violence: The Case of Ethnic Ijaws in Nigeria's Delta Region" Terrorism and Political Violence, I3 (4) (Winter 200I), I5-36

UNCTAD 2013. World Investment Report: Global Value Chains, Investment and Trade for Development. New York and Geneva: United Nations . 2009. World Investment Report: Transnational Corporations. New York and Geneva: United Nations . 2007. World Investment Report: Transnational Corporations, Extractive Industries and Development. New York and Geneva: United Nations

. I999. World Investment Report 1999: Foreign Direct Investment and the Challenge of Development. New York and Geneva: United Nations

UNDP. 20I6. Human Development Report on Nigeria, 20I5. New York: UND United Nations Environment Program (UNEP). 20II. Environmental Assessment of Ogoniland. http://postconflict.unep.ch/publications/OEA/ UNEP_OEA.pdf

Wig A. and Kolstad, I. 20I0. "Multinational Corporations and Host Country Institutions: A Case Study of CSR Activities in Angola", International Business Review I9 (2) I78-I90 


\begin{abstract}
Scholarly works on development studies have revealed that MNCs' penetration into the economy of developing countries would herald stable economic growth and social cohesion. But so far, outcomes have worsened economic inequality, and even led to violent conflicts. These myriads of problems have brought huge concerns on the relevance of MNCs. It is against this backdrop that this paper unveils the role of MNOCs in the political economy of Niger Delta, the subordination of State's role to the interests of MNOCs, and the effects of the triple alliance between foreign capital, national capital and State on the region.
\end{abstract}

\title{
KEYWORDS
}

MNOCs; region of the Niger Delta; Crude Oil; development.

Received on October 10, 2018. Approved on January 13, 2019. 